Check for updates

Cite this: RSC Adv., 2017, 7, 19211

Received 24th January 2017

Accepted 24th March 2017

DOI: 10.1039/c7ra01081h

rsc.li/rsc-advances

\section{Headway in rhodanide anion based ternary gel polymer electrolytes (TILGPEs) for applications in rechargeable lithium ion batteries: an efficient route to achieve high electrochemical and cycling performances $\uparrow$}

\author{
K. Karuppasamy, (D) *ab K. Prasanna, ${ }^{\mathrm{C}}$ Dongkyu Kim, ${ }^{a}$ Yong Hee Kang ${ }^{\mathrm{a}}$ \\ and Hee Woo Rhee*a
}

In this present investigation, we developed a new category of rhodanide anion based ternary gel polymer electrolytes (TILGPEs) with high electrochemical and thermal stability, which advantageously use the harmonizing properties of a temperature-responsive polymer poly vinylidene fluoride-cohexafluoropropylene (PVdF-co-HFP) and room temperature ionic liquid (1-ethyl-3-methylimiazolium rhodanide (thiocyanate), (EMImSCN)). TILGPEs were fabricated using a facile solution cast method by incorporating EMImSCN and lithium rhodanide (LiSCN) into PVdF-CO-HFP based membranes. Among the series of electrochemical tests including electrochemical impedance spectroscopy, cyclic voltammetry, linear sweep voltammetry and chronoamperometry, the membrane with 80 wt\% electrolyte mixtures (EMImSCN/LiSCN) showed better performance in all aspects. The maximum ionic conductivity was found to be in the order of $2.8 \times 10^{-4} \mathrm{~S} \mathrm{~cm}^{-1}$ at $298 \mathrm{~K}$. The LiFePO $4 /$ TILGPE3/Li cell offered a maximum discharge capacity of $149.8 \mathrm{~mA} \mathrm{~h} \mathrm{~g}^{-1}$ at $\mathrm{C} / 10$ rate. The inimitable properties allowed the effective use of the rhodanide TILGPEs as active separators for the development of advanced lithium ion batteries.

\section{Introduction}

During the past three decades, rechargeable lithium ion batteries have received great consideration as the most plausible next generation of power sources for electric vehicles and portable electronic devices due to their relatively high specific energy storage capabilities. ${ }^{\mathbf{1 - 4}}$ Nevertheless the utilization of flammable liquid electrolytes in rechargeable secondary batteries upsurges the safety concerns. ${ }^{5}$ Therefore, substituting flammable electrolytes and enhancing the energy density of batteries are at the forefront of research in both academia and industry. Gel polymer electrolytes (GPEs) have been intensively studied as an alternative to their liquid counterparts. The foremost benefits of GPEs in lithium ion batteries (LIBs) lies with their high ionic conductivity and non-leakage nature, as compared to those spotted for liquid electrolytes, and their capacity to construct electrolytes as flexible

aPolymer Materials Lab, Department of Chemical and Biomolecular Engineering, Sogang University, 35 Baekbeom-ro, Mapo-Gu, Seoul 04107, South Korea. E-mail: karuppasamyiitb@gmail.com; hwrhee@sogang.ac.kr

${ }^{b}$ Division of Electronics and Electrical Engineering, Dongguk University-Seoul, Seoul 04620, South Korea

${ }^{c}$ Electrochemical Energy Storage and Conversion Lab (EESC), Kyung Hee University, 1732, Deogyeong-daero, Giheung-gu, Yongin, Gyeonggi 17104, South Korea

$\dagger$ Electronic supplementary information (ESI) available. See DOI: $10.1039 / \mathrm{c} 7 \mathrm{ra} 01081 \mathrm{~h}$ thin films leading to greater energy density in batteries. ${ }^{6-8}$ Utmost of the reported GPEs are consisted of liquid electrolyte solution of salts in volatile organic carbonate solvents such as ethylene carbonate (EC), diethyl carbonate (DEC), propylene carbonate (PC) and so forth immobilizing in polymer host matrix. But when considering organic solvents for GPEs preparation, the major drawbacks that we generally come across is their meager thermal and electrochemical properties with organic solvents that are volatile in nature, and their relatively narrow electrochemical potential window., ${ }^{7,8}$

In order to overcome the above said issues, scientists and researchers have employed various types of additives to enhance electrochemical and cycling stability greater to most organic solvents. Among them, room temperature ionic liquids (ILs) are a very promising class of candidate for the fabrication of GPEs which would allow for the construction of batteries with reduced fire hazards due to its negligible vapor pressure and low flammability. ${ }^{9-12}$ It also functions as solvent to plasticize ioncoordinating polymers and to dissolve lithium salts, promoting fast ions migration. ${ }^{13}$ Also in the past, numerous polymers were investigated as hosts for GPEs system including PVdF-co-HFP, PEO, PMMA, PAN and so forth. ${ }^{\mathbf{1 4 - 1 8}}$ Between them, PVdF-co-HFP is considered to be the best because of high electrochemical stability and its ability to dissolve lithium salts due to its high dielectric constant $(\varepsilon=11.38)$ in amorphous phase. ${ }^{19-22}$ 
Past one decade, prodigious deals of efforts have been devoted to improve the ionic conductivity and performance of gel electrolytes for LIBs. Quite a lot of anions based electrolyte mixtures such as $\mathrm{TFSI}^{-}, \mathrm{CF}_{3} \mathrm{SO}_{3}{ }^{-}, \mathrm{BF}_{4}{ }^{-}$, nonaflate are successfully used as gel polymer electrolytes in lithium-ion battery. ${ }^{23-28}$ Among them, rhodanide anion (familiarly known as thiocyanate $\mathrm{SCN}^{-}$) is believed to be most promising anion for electrolyte preparation because it has a strong electron withdrawing group, possesses a lower LUMO (Low Unoccupied Molecular Orbital) and a higher electrochemical stability for wide electrochemical window towards batteries with high energy. ${ }^{29,30}$ In the present study, we report a new class of ternary gel polymer electrolyte (TILGPEs) membranes prepared by encompassing rhodanide anion based lithium salt and ionic liquid [1-ethyl-3methylimidazolium rhodanide (EMImSCN)] into a PVdF-co-HFP matrix. Lithium rhodanide is of quite interest due to the fact that it is thermally stable at elevated temperatures, insensitive to ambient moisture, eco-friendly (non-toxic) as compared to other conventional lithium salts. ${ }^{31,32}$ A synergistic effect of electrolyte mixture (LiSCN/EMImSCN) on the electrochemical and cycling performance of TILGPEs has been observed and will be discussed in this work and also, there were no previous report on LiSCN/EMImSCN as active materials for electrolytes in LIB applications. The detailed investigations on electrochemical behavior of TILGPEs have been characterized using impedance analysis (EIS), cyclic voltammetry, chronoamperometry and charge discharge analysis and the significant results are presented herein.

\section{Experimental}

\subsection{Materials}

Poly(vinylidinefluoride-co-hexafluoropropyline) (PVdF-co-HFP pellets, average molecular weight, $M_{\mathrm{w}} 4 \times 10^{5}$ ), 1-ethyl-3-methyl imidazolium thiocyanate (EMImSCN, $\geq 99.1 \%$ pure, $\mathrm{H}_{2} \mathrm{O}$ impurities: $<0.12 \%$ (Karl-Fischer titration) and $M_{\mathrm{w}}$ 169.25) and lithium rhodanide (LiSCN, anhydrous basis, $M_{\mathrm{w}} 65.02$ ) were purchased from Aldrich. The lithium salt and ionic liquid were kept under vacuum at $70{ }^{\circ} \mathrm{C}$ for $12 \mathrm{~h}$ prior to use. In the whole preparation process, anhydrous acetonitrile (Aldrich) was used as solvent.

\subsection{Preparation of ternary gel polymer electrolytes} (TILGPEs)

The electrolyte mixture LiSCN/EMImSCN was prepared by dissolving $0.3 \mathrm{M}$ of LiSCN in the neat ionic liquid EMImSCN and it was subjected to constant magnetic stirring at $60{ }^{\circ} \mathrm{C}$ until homogeneous solution was obtained. The gel polymer electrolyte films were prepared using facile solution cast technique. $^{28}$ In this method, the mixtures of LiSCN/ EMImSCN and PVdF-co-HFP were prepared in different ratios as shown in Table 1 . Initially, the polymer host PVdFco-HFP was dissolved in anhydrous acetonitrile separately. After that, various weight ratios of electrolyte mixture and PVdF-co-HFP solution were then mixed using a magnetic stirrer in a one necked flask at $60{ }^{\circ} \mathrm{C}$ for $12 \mathrm{~h}$. The obtained pasty mass solution was transferred into Teflon Petri dishes and then dried under vacuum for $24 \mathrm{~h}$. The resulting dimensionally free standing TILGPEs having a thickness of 150-180 $\mu \mathrm{m}$ (as shown in Fig. S1 of ESI $\dagger$ ) was stored in an inert atmosphere for further characterizations.

\subsection{Materials characterizations}

The X-ray diffraction analysis of prepared gel electrolytes were carried out using an X-ray diffractometer (D-MAX 2500, Rigaku) with $\mathrm{Cu}-\mathrm{K} \alpha$ radiation $(\lambda=1.5406 \AA)$ generated at $40 \mathrm{kV}$ and 30 $\mathrm{mA}$ flux in the $2 \theta$ range between 0 and $100^{\circ}$ at ambient temperature. The differential scanning calorimetry (DSC) measurement of pure polymer host and TILGPEs were made on TA Instruments, (Model 2920) thermal analyzer at a heating rate of $10{ }^{\circ} \mathrm{C} \mathrm{min}^{-1}$ under nitrogen atmosphere in the temperature range of -50 to $200{ }^{\circ} \mathrm{C}$. The thermogravimetry (TGA) analysis of TILGPEs was carried out on a TGA-2950 thermal analyzer (HiRes, TA instruments) by heating from 25 to $700{ }^{\circ} \mathrm{C}$ under a $\mathrm{N}_{2}$ atmosphere at a heating rate of $20{ }^{\circ} \mathrm{C} \mathrm{min}^{-1}$. FTIR spectra were recorded with the help of a Nicolet 380 FT-IR spectrometer (Thermo Electron) in the region $4000-400 \mathrm{~cm}^{-1}$ at a signal resolution of $1 \mathrm{~cm}^{-1}$.

The ionic conductivities of the prepared TILGPEs were analyzed by electrochemical impedance spectroscopy (EIS). The electrolyte samples analysis was performed in blocking type cells where the TILGPEs were sandwiched between two stainless steel electrodes. The ionic conductivity of the TILGPEs having an area of $1.7665 \mathrm{~cm}^{2}$ were measured using ac-impedance spectroscopy (Ivium Technologies, Netherlands) in the frequency range $\left(1-10^{6}\right) \mathrm{Hz}$ with amplitude signal of $10 \mathrm{mV}$. The temperature dependence of ionic conductivity was performed in the temperature range between 298 and $398 \mathrm{~K}$. The ionic conductivity was evaluated from the intercept of the low frequency spike with the real axis obtained from impedance measurements. ${ }^{32}$ The ionic conductivity of TILGPEs was calculated from eqn 1

Table 1 Composition of TILGPES and its corresponding values of $E_{\mathrm{a}}, \sigma, \% \alpha, T_{\mathrm{m}}, T_{\mathrm{g}}$, thermal stability and electrochemical stability ${ }^{a}$

\begin{tabular}{llllllll}
\hline TILGPEs & $E_{\mathrm{a}}(\mathrm{eV})$ & $\sigma$ at $398 \mathrm{~K}\left(\mathrm{~S} \mathrm{~cm}^{-1}\right)$ & Anodic stability $(\mathrm{V})$ & $T_{\mathrm{g}}\left({ }^{\circ} \mathrm{C}\right)$ & $T_{\mathrm{m}}\left({ }^{\circ} \mathrm{C}\right)$ & Crystallinity $\% \alpha$ & Thermal stability $\left({ }^{\circ} \mathrm{C}\right)$ \\
\hline TILGPE1 & 0.283 & $3.5 \times 10^{-4}$ & 3.40 & -32.23 & 139.63 & 46.31 & 251 \\
TILGPE2 & 0.178 & $3.3 \times 10^{-3}$ & 3.50 & -30.64 & 130.61 & 43.42 & 252 \\
TILGPE3 & 0.026 & $2.8 \times 10^{-2}$ & 3.60 & -27.81 & 115.41 & 41.80 & 256
\end{tabular}

${ }^{a}$ TILGPE1 (60\% LiSCN/IL + 40\% PVdF-HFP), TILGPE2 (70\% LiSCN/IL + 30\% PVdF-HFP) and TILGPE3 (80\% LiSCN/IL + 20\% PVdF-HFP). 


$$
\sigma=t / R_{\mathrm{b}} A
$$

where $t$ is the thickness of the TILGPEs, $R_{\mathrm{b}}$ is the bulk resistance and $A$ is the area of electrode-electrolyte contact.

The total lithium transference number $\left(t_{\mathrm{Li}^{+}}\right)$of prepared TILGPEs was measured using AC impedance and DC polarization method. A step voltage of $20 \mathrm{mV}$ was applied across the symmetrical Li/TILGPE3/Li cell and the resulting current was measured as a function of time (chronoamperometry) at 333 K. ${ }^{32}$ The lithium transference number $\left(t_{\mathrm{Li}^{+}}\right)$of TILGPE was obtained by eqn (2)

$$
t_{\mathrm{Li}^{+}}=\frac{I_{\mathrm{ss}}\left(\Delta V-R_{0} S_{0}\right)}{I_{0}\left(\Delta V-R_{\mathrm{ss}} I_{\mathrm{ss}}\right)}
$$

where, the subscripts 0 and ss represents initial values and steady state values, respectively, $R_{\mathrm{b}}$ is the bulk resistance, $R$ is the passive film resistance, and their values can be evaluated from the Nyquist curves of the TILGPE before and after the experiment. $\Delta V$, the applied voltage and $I$ is the current.

The linear sweep voltammetry and cyclic voltammetry analyses of TILGPEs were examined using Li/TILGPEs/Li symmetric cell at $298 \mathrm{~K}$. These analyses were carried out using Ivium Technologies electrochemical workstation. For LSV, the potential range fixed from 0 to $5 \mathrm{~V}$ at a scan rate of $20 \mathrm{mV} \mathrm{s}^{-1}$. CV analysis was performed at different scan rates in the potential limit between -5 and $+5 \mathrm{~V}$. The cycling performance of TILGPE3 was observed in galvanostatic mode using BT2000 Arbin cycler. Charge-discharge analysis was carried out for the 2032 coin cell assembled by sandwiching the TILGPE3 between the commercially available $\mathrm{LiFePO}_{4}$ cathode foil (MTI corporations) and lithium metal anode. The coin cell was cycled between the cutoff voltage of 2.7 and $4.1 \mathrm{~V}$ at five different C-rates at room temperature.

\section{Results and discussions}

\subsection{Crystalline behavior of ternary gel polymer electrolytes}

The XRD patterns of pure PVdF-co-HFP, TILGPE-1, TILGPE-2 and TILGPE-3 respectively are shown in Fig. 1. The peaks observed at $2 \theta=20.38,39.12$ and 41.26 (corresponds to $\left(\begin{array}{lll}1 & 0 & 0\end{array}\right)$, ( $\left(\begin{array}{lll}0 & 2 & 0\end{array}\right)$ and ( $\left.\begin{array}{lll}0 & 2 & 1\end{array}\right)$ reflection planes respectively) reveal the partial crystallization of PVdF units present in the complexes, giving an overall semi crystalline morphology of PVdF-coHFP. $^{33,34}$ The XRD patterns of TILGPEs show decrease of intensity of the semi-crystalline peak of pure PVdF-co-HFP with the addition of electrolyte mixture content. This is due to the enhanced amorphicity of the prepared membranes. Furthermore, no peaks are found for electrolyte mixture (LiSCN/ EMImSCN) reveals the completely dissolution of electrolyte mixture in the polymer matrix. This result is similar to the result obtained by Qingqing Zhang et al. ${ }^{35}$ The lowest intensity is achieved with incorporation of $80 \mathrm{wt} \%$ of rhodanide electrolyte mixture. Subsequently, the variation of intensity in gel polymer electrolytes after the addition of rhodanide electrolyte mixture can be expected as the evidence of complexation between PVdFco-HFP polymer and rhodanide electrolyte mixture. The results suggest that adding electrolyte mixture into PVdF-co-HFP can

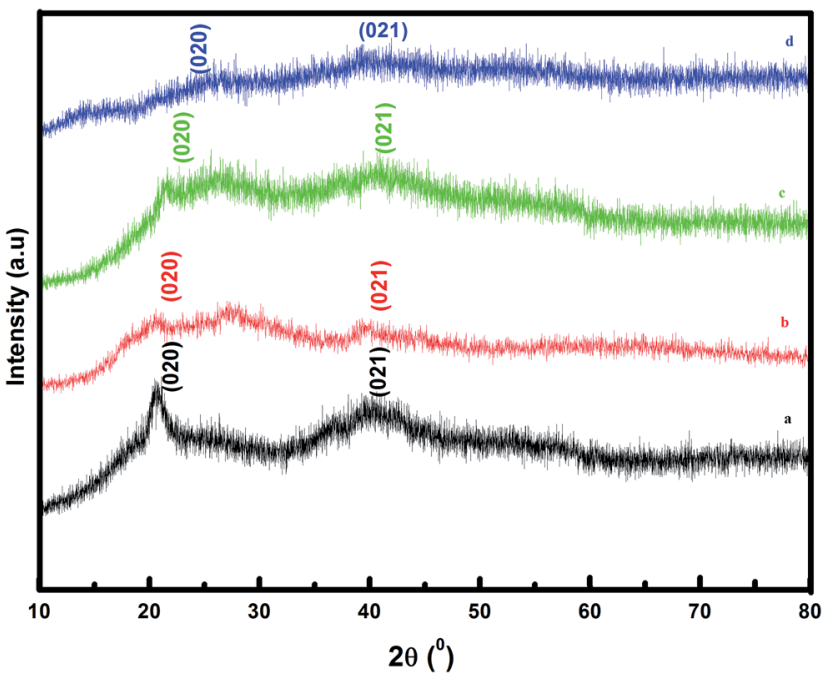

Fig. 1 (a-d) XRD patterns of pristine PVdF-CO-HFP, TILGPE1, TILGPE2 and TILGPE3.

reduce the crystallinity and increase the amorphous areas of polymer matrix thereby enhances ionic conductivity of the TILGPEs. In other words, the broadening of peak in the diffractogram is a clear evidence for amorphous nature (due to polymer segmental motion enhancement) which is responsible for ionic conductivity of TILGPEs which will be discussed later in the following sections.

DSC analysis is performed to validate the XRD results as well as to evaluate change in crystallinity in gel polymer matrix in the temperature range between -50 and $200{ }^{\circ} \mathrm{C}$. The DSC thermogram of pristine PVdF-co-HFP and electrolyte mixture (EMImSCN/LiSCN) in the temperature range are shown in Fig. S2 (see ESI $\dagger$ ). It is observed from the thermogram that the pristine PVdF-co-HFP and electrolyte mixture shows a sharp melting endotherm $\left(T_{\mathrm{m}}\right)$ at $142{ }^{\circ} \mathrm{C}$ and $125{ }^{\circ} \mathrm{C}$ respectively. The glass transition temperature $\left(T_{\mathrm{g}}\right)$ of PVF-co-HFP appears around $-35{ }^{\circ} \mathrm{C}$. Fig. 2 represents the DSC thermogram of different ternary gel electrolytes namely TILGPE1, TILGPE2 and TILGPE3 in the temperature range between $-50{ }^{\circ} \mathrm{C}$ and $200{ }^{\circ} \mathrm{C}$. As shown in figure the $T_{\mathrm{m}}, T_{\mathrm{g}}$ and \% $\alpha$ (degree of crystallinity) of the prepared TILGPEs move towards lower temperature side upon the addition of different weight percent of electrolyte mixture in the polymer which is due to the plasticization effect of electrolyte mixture. The presence of electrolyte mixture in PVdF-co-HFP matrix weakened the interactive bonds between the chains within the gel electrolytes which in turn reduces the amount of energy consumed to break the bond. ${ }^{36,37}$ Among the prepared TILGPEs, the gel electrolyte with $80 \%$ electrolyte mixture shows a low value of melting temperature $\left(T_{\mathrm{m}}\right)$. i.e., it is clearly seen from Fig. 2(a) that the melting temperature $\left(T_{\mathrm{m}}\right)$ of pure host decreases from 142 to $115.41{ }^{\circ} \mathrm{C}$ which is usually detected in various PVdF-co-HFP based systems. ${ }^{38,39}$ Similarly the value of $T_{\mathrm{g}}$ and $\alpha$ also reduces further in the presence of electrolyte mixture as shown in Fig. 2(b). The inclusion of LiSCN/EMImSCN in polymer matrix not only elevates the $T_{\mathrm{g}}$ of TILGPEs $\left(\sim-35^{\circ} \mathrm{C}\right)$ but also broadens the $T_{\mathrm{g}}$ zone. This is due to the fact that the 

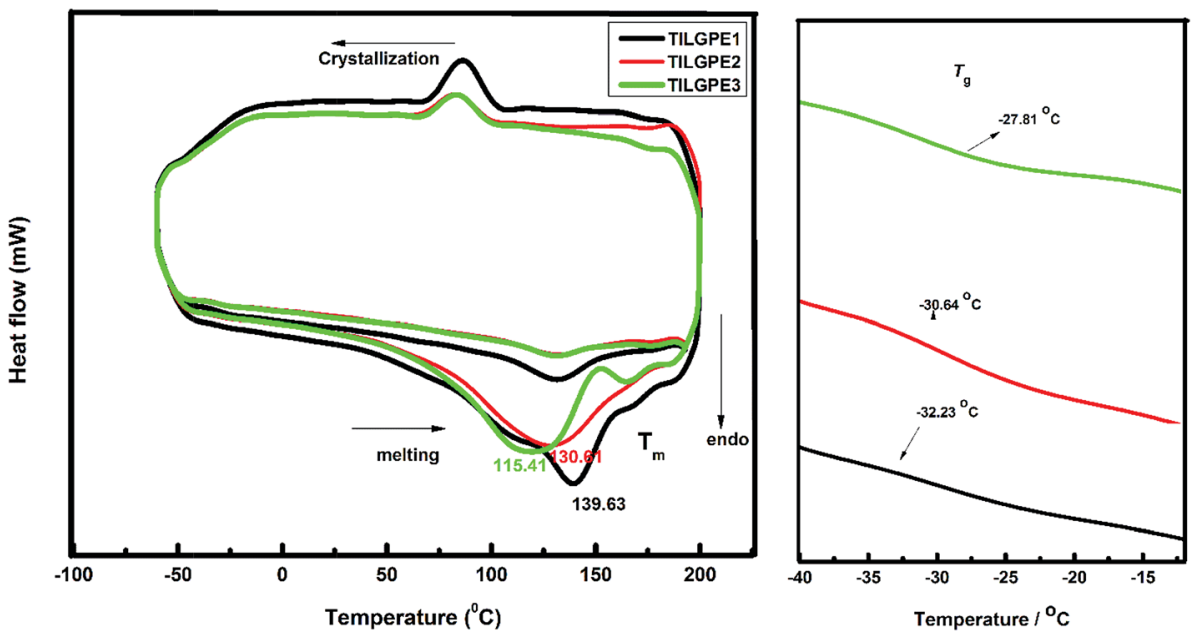

Fig. 2 DSC thermogram curves of TILGPE1, TILGPE2 and TILGPE3.

flexibility of polymer chains in the immediate vicinity of the ion-polymer complex site may behave differently from that in the bulk polymer matrix network. ${ }^{40}$ Its resultant values are summarized in Table $1 .^{8}$ The degree of crystallinity $(\% \alpha)$ of the prepared TILGPEs are estimated from the ratio of the area under melting peak (which is a measure of melting heat $\left(\Delta H_{\mathrm{m}}\right)$ involved in the phase transition) to the melting heat $\Delta H_{\mathrm{m}} 100 \%$ of $100 \%$ crystalline PVdF-co-HFP as per equation,

$$
\% \alpha=\Delta H_{\mathrm{m}} / \Delta H_{\mathrm{m}} 100 \% \times 100
$$

The value of $\Delta H_{\mathrm{m}} 100 \%$ is heat of fusion of $100 \%$ crystalline PVF-co-HFP which is taken as $104.5 \mathrm{~J} \mathrm{~g}^{-1} .{ }^{8}$ As it is evident from the table that the value of $\% \alpha$ decreases with increase in electrolyte mixture content which indicates the increase in flexibility and mobility of the polymer chain segment in PVdF-coHFP. As a result, the amorphous fraction in TILGPEs increases gradually thereby leads to increase the ionic conductivity which will be discussed later.

The thermal stability of the prepared ternary gel electrolytes was examined by thermogravimetric analysis (TGA) in the temperature range between 30 and $700{ }^{\circ} \mathrm{C}$. The thermogram of pristine PVdF-co-HFP and electrolyte mixture LiSCN/EMImSCN are shown in Fig. S3 (see ESI $\dagger$ ). For pure PVdF-co-HFP, there is no initial weight loss upto $406{ }^{\circ} \mathrm{C}$ whereas in the case of electrolyte mixture, the initial weight loss of $3-4 \%$ before $100{ }^{\circ} \mathrm{C}$ may due to absorption of moisture or water molecules during loading of sample. Moreover the electrolyte mixture is thermally stable up to $190^{\circ} \mathrm{C}$. Fig. 3 shows the TGA data for various ternary gel polymer electrolytes. On blending PVdF-co-HFP with different weight percentages of electrolyte mixture enhances the thermal stability of the gel electrolyte considerably. The TGA plots of all the TILGPEs show that steepest decomposition starts at a temperature higher than $250{ }^{\circ} \mathrm{C}$. As can be seen, the TILGPEs shows a significant weight loss of $4 \%$ before $100{ }^{\circ} \mathrm{C}$ due to absorption of moisture and this little weight loss below $256{ }^{\circ} \mathrm{C}$ indicating a wide operating temperature range, which is important for many practical applications. Above $256{ }^{\circ} \mathrm{C}$, there was a significant weight loss, which is attributed to the rupture of the electrolyte mixture from PVdF-co-HFP. The steepest weight loss was observed after $256{ }^{\circ} \mathrm{C}$, which is attributed to both the degradation of the polymer backbone VdF and HFP. ${ }^{41}$ It is quite observed from the thermogram that the thermal stability of TILGPE3 is slightly higher than other two electrolytes. Such dissimilarity in thermal stability is attributed to the increase in content of electrolyte mixture in polymer matrix which is in concurrent with earlier reported result. ${ }^{26}$ Also, the temperature at around $256{ }^{\circ} \mathrm{C}$ for initiating thermal decomposition of TILGPEs is higher than the reported thermal stability of other imidazolium based ionic liquids complexed with PVdFco-HFP. ${ }^{38}$

\subsection{Confirmation of ion-polymer interactions in TILGPES}

In the present work, FT-IR analysis has been performed to investigate the ions and ionic liquid interaction within the

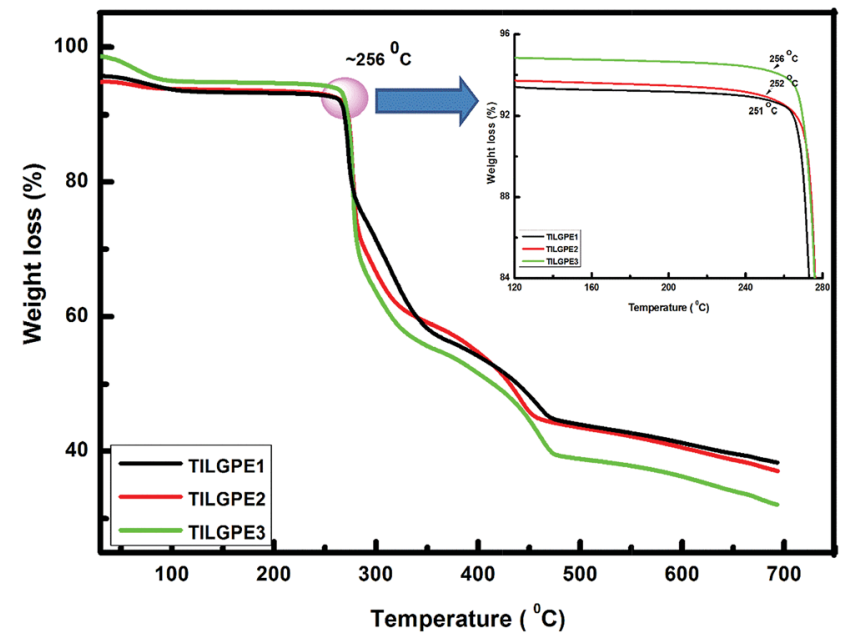

Fig. 3 TGA curves of TILGPE1, TILGPE2 and TILGPE3. 
PVdF-co-HFP host matrix. Fig. 4 depicts the FT-IR spectra of pure polymer host and different types of TILGPEs. As can be seen that the peaks appear at $1120 \mathrm{~cm}^{-1}$ and $1040 \mathrm{~cm}^{-1}$ belongs to asymmetrical stretch of $\mathrm{CF}_{2}$ group and bending of $\mathrm{CF}_{3}$ group of pure PVdF-co-HFP. ${ }^{42-44}$ Whereas FT-IR spectrum of electrolyte mixture (EMImSCN/LiSCN) shows characteristic peaks at 26002900, 2116, 1640 and $935 \mathrm{~cm}^{-1}$ corresponds to symmetrical $\mathrm{CH}_{2}$ stretching, asymmetrical $\mathrm{C}-\mathrm{N}$ stretching $\left(\nu_{\mathrm{a}}(\mathrm{C}-\mathrm{N})\right), \nu_{\mathrm{a}}(\mathrm{CN})$ and symmetric SCN bending respectively ${ }^{32,45}$ (see ESI Fig. S4 $\dagger$ ). The inclusion of electrolyte mixture in to PVdF-co-HFP matrix preferably interacts with the free electron pairs of fluorine atom $\left(\mathrm{CF}_{2}\right.$ and $\mathrm{CF}_{3}$ group) of host matrix which is evidenced by decrease in intensity of the vibrational peaks as represented in Fig. 4. Hence, to show the coordination between $\mathrm{Li}^{+}$and $\mathrm{EMIm}^{+}$ ions with PVdF-co-HFP, the $\nu_{\mathrm{a}}\left(\mathrm{CF}_{2}\right)$ and $\delta\left(\mathrm{CF}_{3}\right)$ vibrational modes will be examined for shift in wavenumbers towards right, which is an indicator for occurrence of cations $\left(\mathrm{Li}^{+}\right.$and $\left.\mathrm{EMIm}{ }^{+}\right)$ interaction with the polymer host. Also the inclusion of electrolyte mixture in the PVdF-co-HFP matrix is further confirmed by the gradual enhancement of vibrational bands in the regions $2120 \mathrm{~cm}^{-1}$ (belongs to S-CN) and $910-930 \mathrm{~cm}^{-1}(\delta(\mathrm{SCN}))$ which were quite absent in the case of pristine PVdF-co-HFP as displayed in Fig. 5(a). Its ( $\delta(\mathrm{SCN}))$ corresponding deconvolution spectra are shown in Fig. 5(b). From figure, it can be seen that among the gel electrolytes, TILGE3 electrolyte shows an increase in intensity of SCN characteristic bands. The intensity of the five bands of TILGEs keeps increasing with increasing content of electrolyte mixture thereby confirm the presence of both anions and cations of electrolyte mixture in PVdF-co-HFP matrix. The results obtained are in concurrent with the result reported earlier by Arof et al. ${ }^{\mathbf{4 6 , 4 7}}$

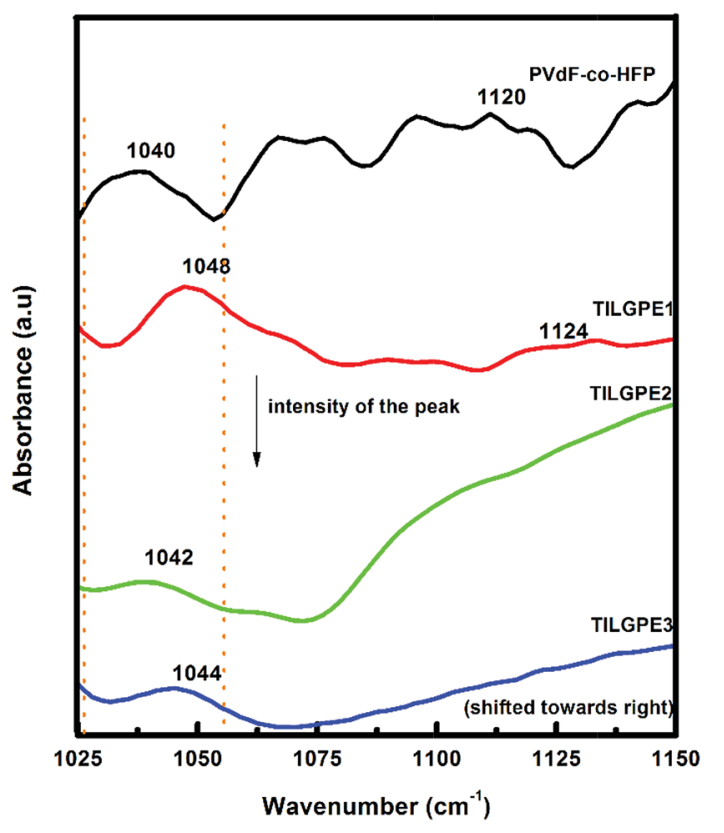

Fig. 4 FT-IR spectrum of PVdF-co-HFP, TILGPE1, TILGPE2 and TILGPE3 in the wavenumber region $1025-1150 \mathrm{~cm}^{-1}\left(\mathrm{CF}_{2}\right.$ and $\mathrm{CF}_{3}$ stretching).
Fig. 6 shows the FTIR spectrum in two different regions namely $3000-2800 \mathrm{~cm}^{-1}$ and $980-840 \mathrm{~cm}^{-1}$ of pristine PVdF-coHFP and TILGPEs containing different weight percentage of electrolyte mixture. These two regions are of our particular attentiveness because we have observed some crucial changes in the peak positions. It is observed from the Fig. 6 that almost all the intense vibrational peaks (2940 and $940 \sim \nu_{\text {as }} \mathrm{CH}_{2}$ and $\delta_{\text {as }}\left(\mathrm{CF}_{3}\right)$ ) belonging to pure polymer host start disappearing and or become weak. While, the characteristic vibrational peaks such as 2970, 2910, 2842, 950, $904 \mathrm{~cm}^{-1}$ of rhodanide electrolyte mixture become prominent as the concentration of electrolyte mixture increases in the polymer host matrix which indicates that electrolyte mixture increases the amorphicity of the polymer gel electrolytes. ${ }^{26}$ The obtained result strongly supports the result that we have found from XRD and DSC studies as discussed earlier.

\subsection{Ionic conductivity of TILGPES}

High ionic conductivity and wide potential electrochemical window are crucial requirement for electrolytes proposed to use for battery applications. ${ }^{\mathbf{8 , 4 , 4 8 - 5 0}}$ In the present investigation, in order to validate the prospective for TILGPEs to be used as gel electrolyte in lithium ion battery and to determine the effect of electrolyte mixture on phase behavior, ionic conductivity measurement were performed for TILGPEs in the dry room at different temperatures. The temperature dependence of ionic conductivity for various TILGPEs in the temperature range between 298 and $398 \mathrm{~K}$ are depicted in Fig. 7(a). From the figure, it seems that it obeys Vogel-Taumann-Fulcher (VTF) relation ${ }^{49}$ as follows

$$
\sigma=\sigma_{0} \mathrm{e}^{-E_{\mathrm{a}}} / R\left(T-T_{0}\right)
$$

where $\sigma$ is the ionic conductivity, $\sigma_{0}$ the pre-exponential factor; $T$ the absolute test temperature, $E_{\mathrm{a}}$ is the apparent activation energy for ionic transport. $R$ and $T$ are the gas constant $(8.314 \mathrm{~J}$ $\mathrm{mol}^{-1} \mathrm{~K}^{-1}$ ) $T_{0}$ is often related to $T_{\mathrm{g}}, T_{0}=T_{\mathrm{g}}-$ const (const $=20-$ $50 \mathrm{~K}$ ) which is far below the measured temperature range (298$398 \mathrm{~K})$. Hence, VTF can be modeled by Arrhenius relation ${ }^{50}$ as follows

$$
\sigma=\sigma_{0} \mathrm{e}^{-E_{\mathrm{a}}} / R T
$$

It is observed from the Fig. 7(a) that the conductivity increases with increase in electrolyte mixture content in a linear fashion which is due to increased number of charge carriers in the host matrix. At $298 \mathrm{~K}$, the conductivity values of TILGPE1, TILGPE2 and TILGPE3 are $2.4 \times 10^{-5}, 3.8 \times 10^{-4}$ and $2.8 \times$ $10^{-4} \mathrm{~S} \mathrm{~cm}^{-1}$ respectively. In addition for high temperature, the conductivity values increases phenomenonly for TILGPE1, TILGPE2 and TILGPE3 ranged from $3.5 \times 10^{-4}, 3.3 \times 10^{-3}$ and $2.1 \times 10^{-2} \mathrm{~S} \mathrm{~cm}^{-1}$ respectively. As is common for typical gel electrolytes, the conductivity values enhances with increasing temperature. This indicates that the polymer chain segmental motion enhances and charge carriers are activated thermally at high temperature thereby favours the migration of lithium ions 
(a)

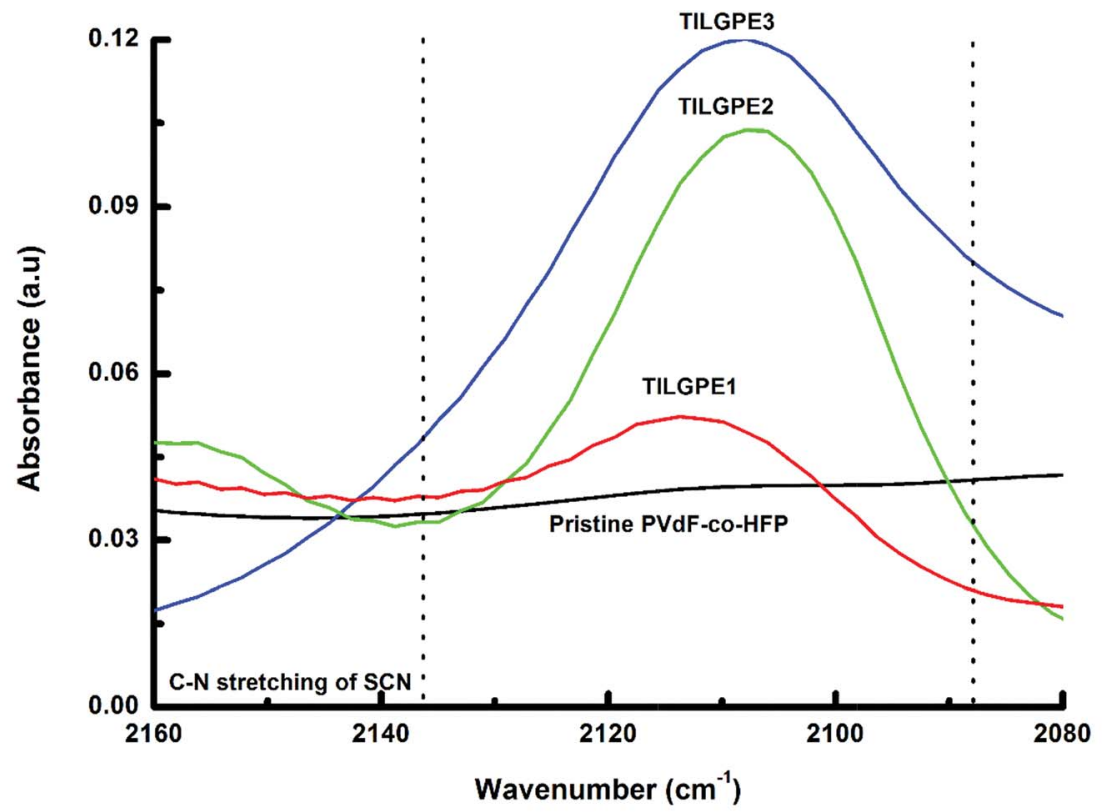

(b)
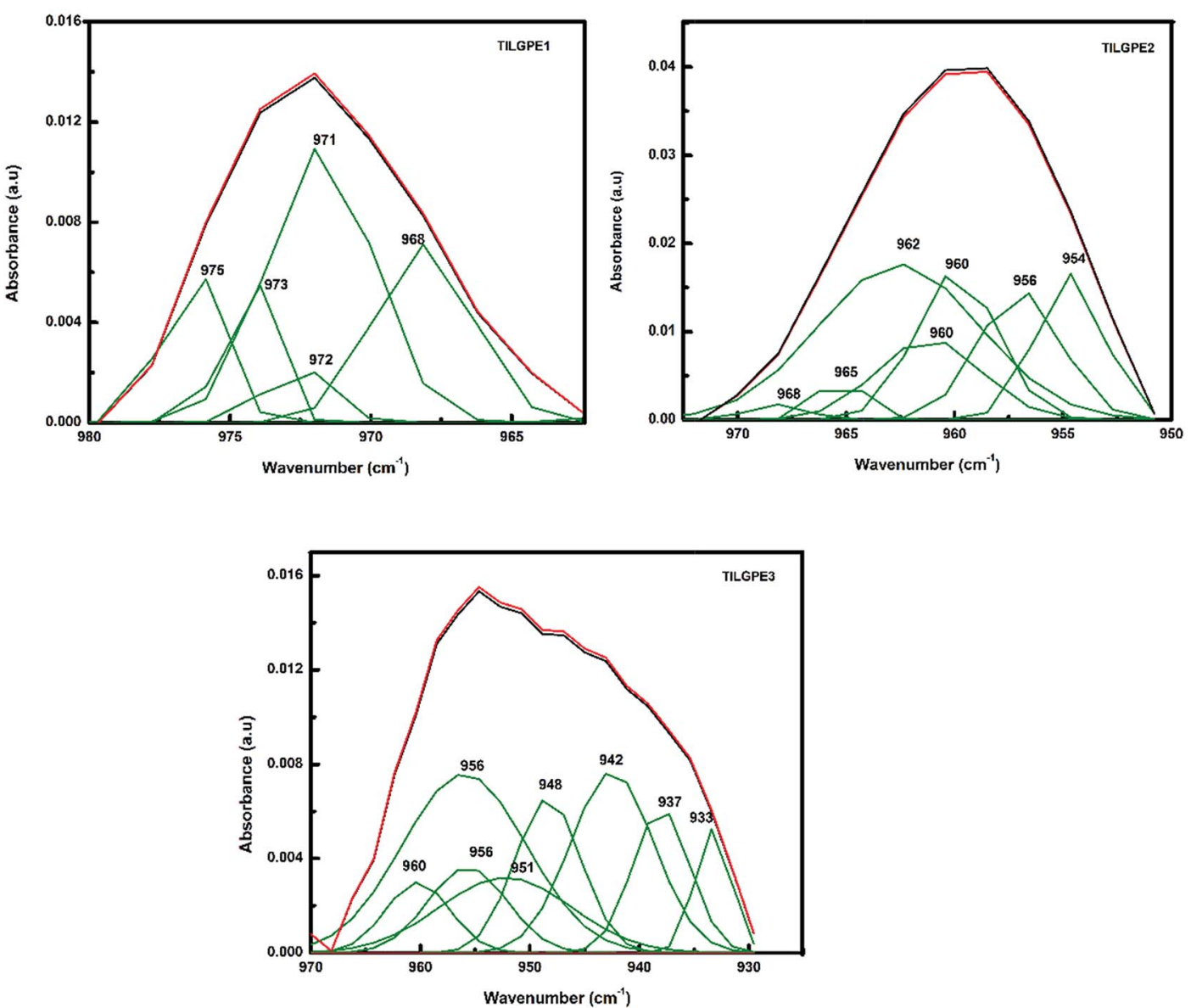

Fig. 5 (a) C-N stretching of SCN in the wavenumber region 2160-2080 (b) Deconvoluted spectra of TILGPE1, TILGPE2 and TILGPE3.

more faster in the polymer host matrix. ${ }^{51}$ Therefore, the ionic conductivity values of TILGPEs are found to be stable over the whole temperature range. Its corresponding values of $\sigma$ and $E_{\mathrm{a}}$ for various TILGPEs are summarized in Table 1. As shown in Fig. 7(b), the value of $E_{\mathrm{a}}$ reduces gradually with increase in electrolyte mixture content which may due to the enhancement 


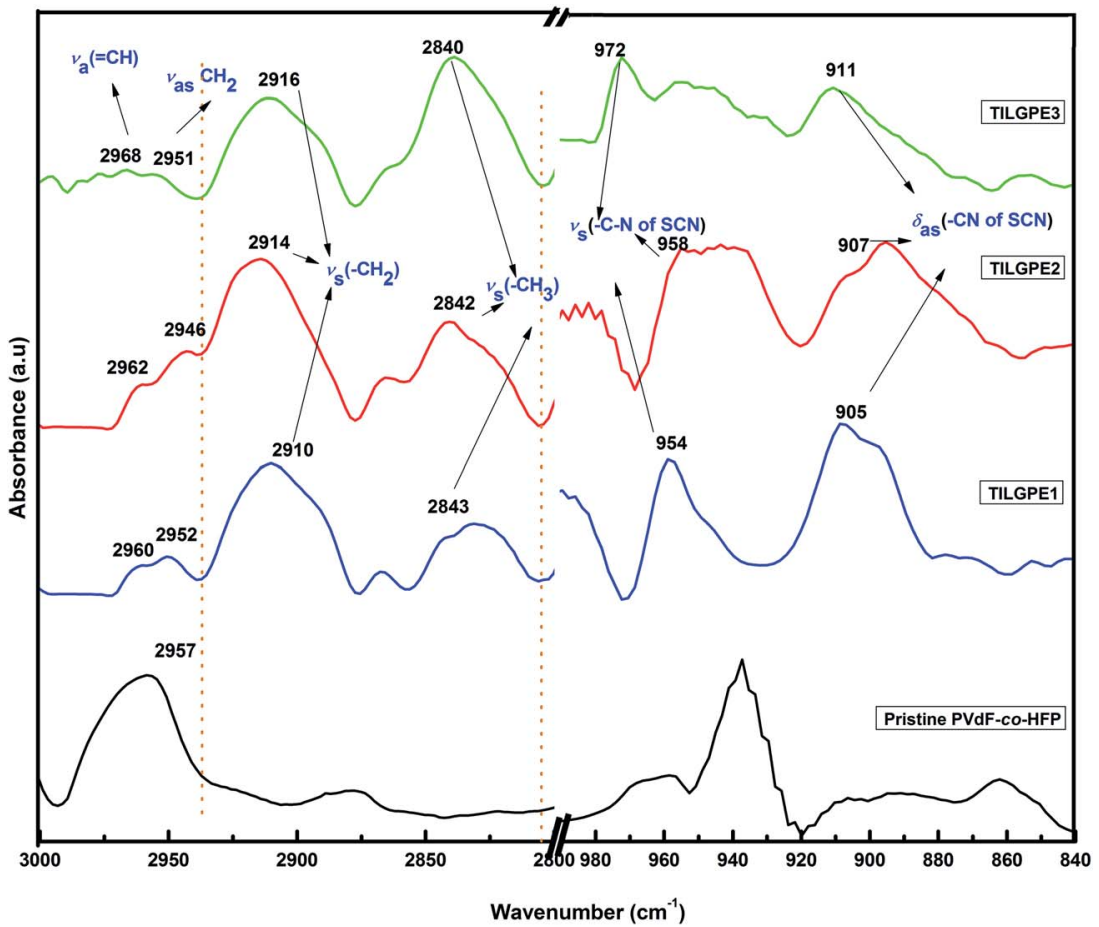

Fig. 6 FT-IR spectrum of PVF-CO-HFP, TILGPE1, TILGPE2 and TILGPE3 in the region between 3000 and $2800 \mathrm{~cm}^{-1} \mathrm{~g} 1000-840 \mathrm{~cm}^{-1}$.

of flexibility of polymer chain thereby increases the amorphous nature and charge carriers in polymer host matrix. ${ }^{52}$ This result firmly strengthens the results obtained by XRD and DSC analyses as discussed earlier.

Further, it is also noticed that among the prepared electrolytes, TILGPE3 possess better conducting property compared to other two electrolytes. Its corresponding Nyquist plot with equivalent circuit is shown in Fig. 7(c). TILGPE3 provides ionic conductivities of the order of $10^{-4} \mathrm{~S} \mathrm{~cm}^{-1}$ at room temperature and achieved a maximum of $10^{-2} \mathrm{~S} \mathrm{~cm}^{-1}$ at $398 \mathrm{~K}$ respectively and it is found to be suitable in entire temperatures range. The results entail that the ionic conductivities of the TILGPE3 from 298 to 398 are all quite higher than that of other PVdF- $c o$-HFP based gel electrolyte system. ${ }^{28}$ These obtained results of TILGPEs show an outstanding potential as a substitute for liquid electrolytes in electrochemical devices with wide range of operating temperatures. The salient features of prepared TILGPE3 is schematically represented in Scheme 1.

So as to improve the performance of the gel electrolytes especially rate and interfacial performance and to understand the migration of lithium ions in the gel matrix, the symmetric cell Li/TILGPE3/Li was subjected to chronoamperometry analysis at $333 \mathrm{~K}$. The reason for choosing electrolyte TILGPE3 is that it yields high ionic conductivity at ambient and high temperatures compared to other two electrolytes. The $t_{\mathrm{Li}^{+}}$of TILGPE3 has been measured by a combining AC impedance and DC polarization method as proposed by Evans et al. ${ }^{33-55}$ Fig. 8 shows the variation of current as a function of time for TILGPE3 at a voltage of $20 \mathrm{mV}$. The value of $t_{\mathrm{Li}^{+}}$for TILGE3 is found to be 0.32 at $70^{\circ} \mathrm{C}$, which is quite comparable to that of other PVdF$c o$-HFP based systems reported in literature earlier. ${ }^{50}$ The $t_{\mathrm{Li}^{+}}$ obtained in the present work is explained by means of a facile mechanism as follows: the Lewis acid sites of electrolyte mixture namely $\mathrm{Li}^{+}$and $\mathrm{EMIm}^{+}$can interact with the electron donor site $\mathrm{CF}_{2}$ of PVdF-co-HFP, $\mathrm{SCN}^{-}$and hence weakened the polymer backbone chain thereby increasing the amorphocity of gel electrolyte which in turn increase the electrical properties. Also, the result thus obtained is well matched with our conductivity results indicating that the increase in charge carriers in gel matrix play a key role in the ionic conductivity increment. Therefore, to conclude that the electrolyte mixture LiSCN/EMImSCN are incorporated to such network of the PVdFco-HFP system, the overall conductivity of the system is high with appropriate transference number. Henceforth, the gel electrolyte TILGPE3 ought be a potential aspirant as separator for rechargeable lithium ion batteries. The observed findings are in concurrent with earlier reporter results by Yusong Zhu et al. ${ }^{18}$ The following sections will describe a profound idea about electrochemical and cycling stability of high conducting TILGPE3 and the details are presented below.

\subsection{Electrochemical stability of TILGPEs}

Electrochemical stability plays a key role to determine the potential application of polymer electrolytes for battery applications. In the present work, we have checked the electrochemical stability window (ESW) of the prepared electrolytes using linear sweep voltammetry analysis in the potential range between 0 and $+5 \mathrm{~V}$ at $298 \mathrm{~K}$ which is the indicator to determine the working voltage range above which the prepared TILGPEs electrolytes remain safe and stable. With that intention, LSV analysis of the TILGPEs was performed by subjecting the 
(a)

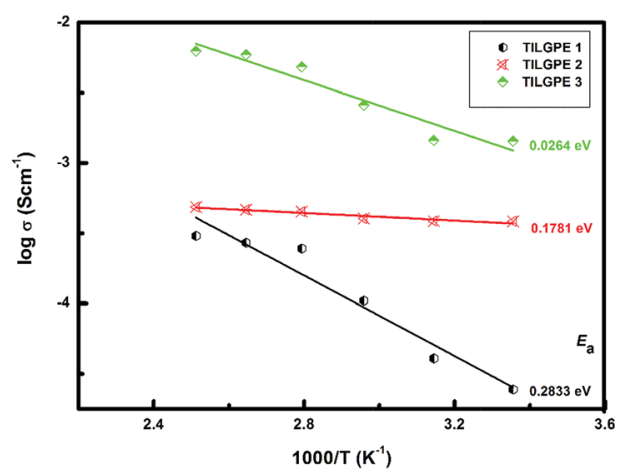

(b)

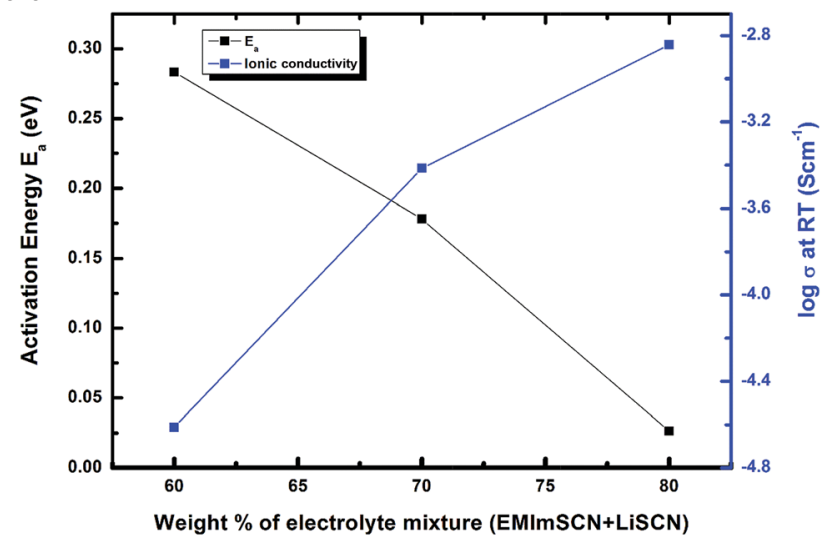

(c)

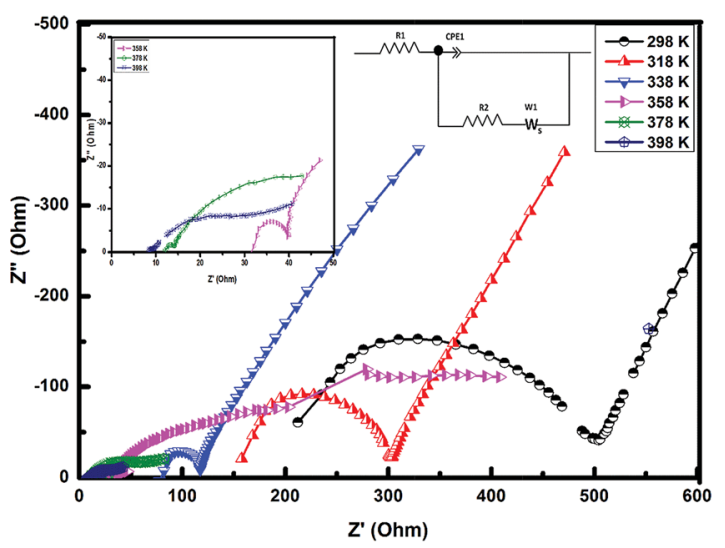

Fig. 7 (a) Temperature dependence of ionic conductivity for TILGPE1, TILGPE2 and TILGPE3 (b) comparison of activation energy and log $\sigma_{\mathrm{RT}}$ as function of electrolyte mixture content (c) Nyquist impedance plot of TILGPE3 and its corresponding equivalent circuit (inset).

symmetrical cell to LSV by means of sandwiching the TILGPE3 electrolyte between lithium electrodes (Li/TILGPE3/Li) and its corresponding results are plotted in Fig. 9(a). In the case of TILGPE1, the anodic stability is around $3.40 \mathrm{~V}$. When the concentration of electrolyte mixture increases from 60 to $80 \%$, the anodic stability limit is further lengthened into $3.60 \mathrm{~V}$, however the catholic current is observed around $2.35 \mathrm{~V}$ (given in inset figure and marked as dotted circle in the main figure). Concerning the lithium anode and $\mathrm{LiFePO}_{4}$ cathode, it shows
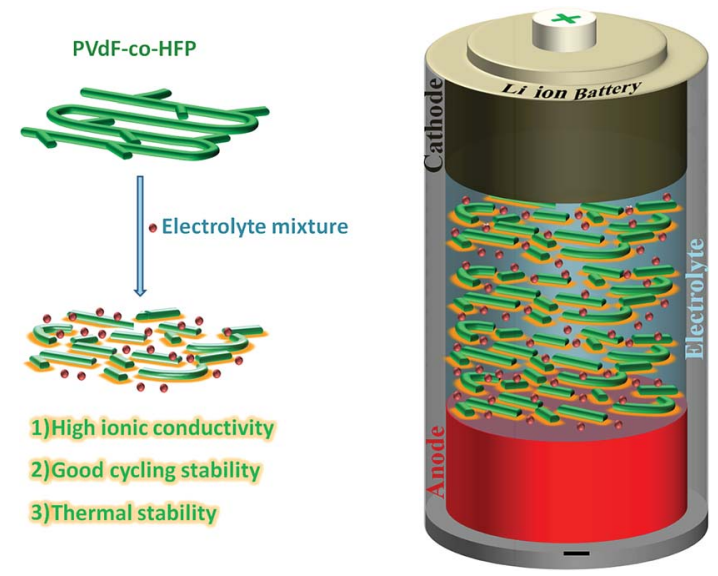

Scheme 1

charge discharging profile plateau in the range between 2.4 and $3.8 \mathrm{~V}$ which exactly lies in the TILGPEs electrochemical potential range thereby demonstrates that the prepared TILGPEs are suitable for lithium anode and $\mathrm{LiFePO}_{4}$ cathode leading to battery applications. The observed results are in strongly concurrent with the earlier reported literatures..$^{19,50,56}$

In order to validate our obtained LSV results as well as to understand the ESW of gel polymer electrolyte, we have performed cyclic voltammetry (CV) measurement at $298 \mathrm{~K}$. Among the three electrolytes, TILGPE3 is of an ultimate interest due to its high conducting property at ambient and elevated temperatures. Hence, in order to understand the ESW of electrolyte system and to know the effect of electrolyte mixture LiSCN/ EMImSCN upon this stability, a symmetrical cell Li/TILGPE3/ Li coin cell was subjected to CV analysis. Fig. 9(b) shows the typical cyclic voltammograms of TILGPE3 electrolyte system recorded at different scan rates $\left(1,5,10\right.$, and $\left.15 \mathrm{mV} \mathrm{s}^{-1}\right)$. The TILGPE3 must not suffer any redox reaction and it doesn't contain any peaks in the operating potential range of the battery, which is set by the potential difference between anode and cathode. Also, it is observed from the voltammogram that it does not show any breakdown or abrupt current enhancement during cycling. This result indicates that the prepared TILGPE3 is electrochemically stable in the operating voltage of battery $(1$ to $3.5 \mathrm{~V}$ ) which is in accordance with earlier reported results by Ravi et al. ${ }^{32}$ Further, CV graph clearly demonstrate that an increase in the scan rate doesn't affect the position and intensity of the voltammogram curve an remains almost constant, which denotes the good reversibility of the TILGPE3. The obtained result suggests that the TILGPE3 is electrochemically active and it is perfectly fit for battery applications. The acquired findings are in consistent with the result reported earlier. ${ }^{42,44,57}$

\subsection{Battery performance of $\mathrm{LiFePO}_{4} / \mathrm{TILGPE} / \mathrm{Li}$ cell}

The high conducting nature of TILGPE3 and their high thermal an electrochemical stability paves way to be a promising candidate along with lithium anode and $\mathrm{LiFePO}_{4}$ cathode in the lithium ion batteries. Taking into consideration of the promising practical applications of the TILGPE3 electrolyte, it was 


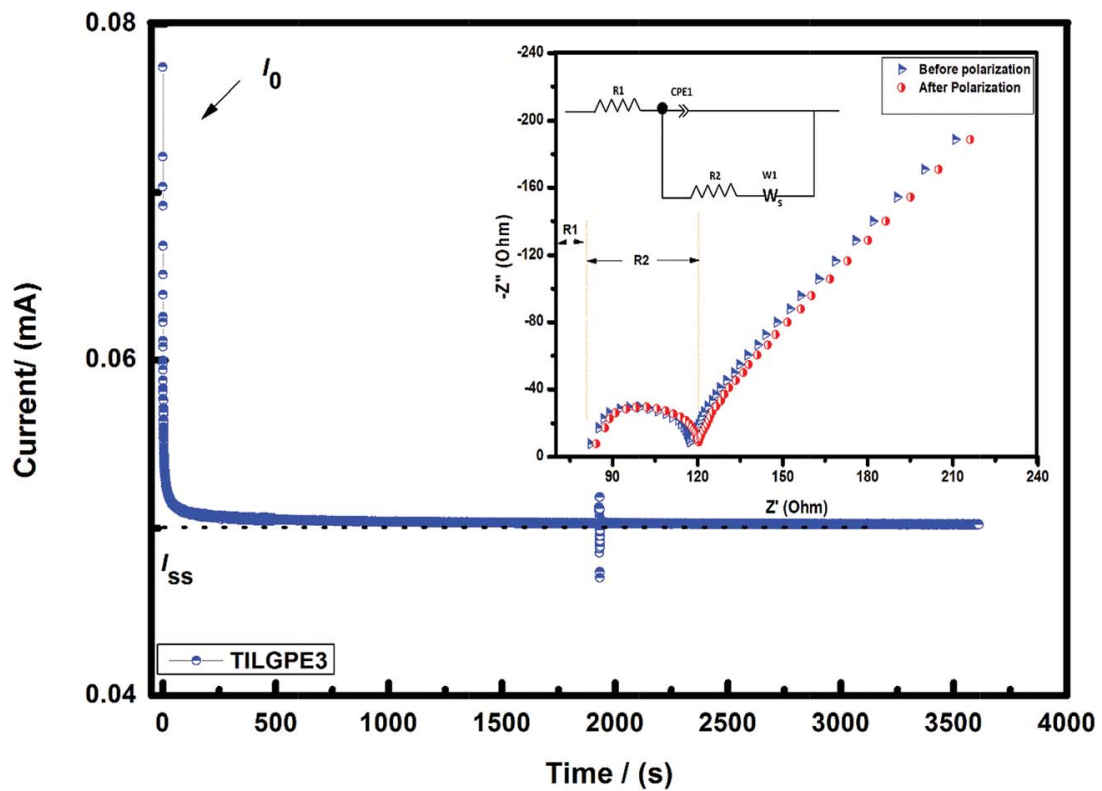

Fig. 8 Chronoamperometry curve of TILGPE3.

(a)

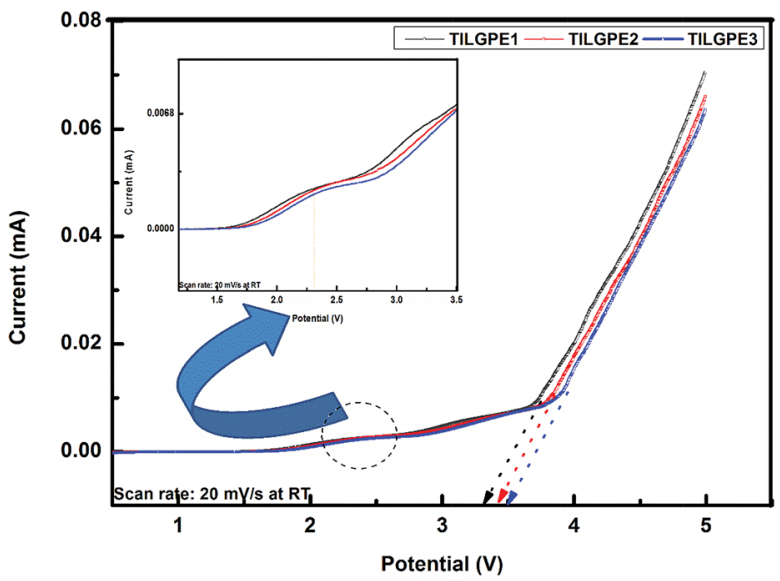

(b)

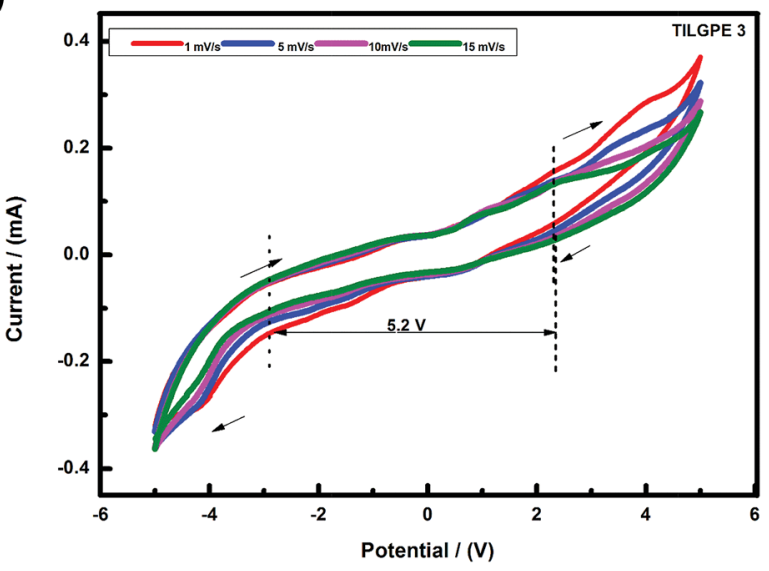

Fig. 9 (a) Linear sweep voltammogram of TILGPE1, TILGPE2 and TILGPE3 (b) cyclic voltammogram of high conducting TILGPE3 at different scan rates. assembled in a $\mathrm{LiFePO}_{4} / \mathrm{Li}$ coin cell. In order to explore the rate performance of the prepared gel electrolyte, the high conducting TILGPE3 was cycled at different current (C) rates at $298 \mathrm{~K}$ as shown in Fig. 10(a). As shown in Fig. 10(a), as the C-rate increases, the specific discharge capacity decreases slightly. In brief, in the first cycle, the cell delivers discharge capacities of $149.2,145.8,141.8,126.4$ and $115.8 \mathrm{~mA} \mathrm{~h} \mathrm{~g}^{-1}$ respectively for $\mathrm{C} /$ $10, \mathrm{C} / 4, \mathrm{C} / 5,1 \mathrm{C}$ and $2 \mathrm{C}$ current rates which is about 87.6 to $68.1 \%$ of the theoretical capacity of the active material LiFePO ${ }_{4} \cdot{ }^{58}$ The decrease in discharge capacities of gel electrolytes may occur due to the formation of passive layers over the lithium electrode surface during cycling. ${ }^{59}$

Fig. 10(b) shows the typical charge-discharge curves of the assembled lithium ion cells with TILGPE3 membranes at the Crate of $0.1 \mathrm{C}$. The charge and discharge plateaus are around $3.4 \mathrm{~V}$ and $3.1 \mathrm{~V}$ respectively which is quite resembles with already reported literature using $\mathrm{LiFePO}_{4} / \mathrm{Li}$ electrodes. ${ }^{58}$ Upon continuous cycling, the discharge capacity decreases slightly and the cell to end with a discharge capacity of $144.3 \mathrm{~mA} \mathrm{~h} \mathrm{~g}{ }^{-1}$ on thirtieth cycle. Furthermore, a small drop from $149.8 \mathrm{~mA} \mathrm{~h} \mathrm{~g}^{-1}$ to $144.3 \mathrm{~mA} \mathrm{~h} \mathrm{~g}^{-1}$ in the discharge capacity may due to the formation of a solid electrolyte interface at the surface or electrodes. This is clearly represented in capacity retention curve at C/10 rate as shown in Fig. 10(c). Also, the columbic efficiency of the first cycle is merely $99.2 \%$ which increases steadily upon cycling and attains a value of $98.7 \%$ in the thirtieth cycle as shown in the inset of Fig. 10(c). Also, the capacity retention curve at different C-rates of $\mathrm{LiFePO}_{4} / \mathrm{TILGPE} / \mathrm{Li}$ cell is displayed in Fig. 10(d). The prepared $\mathrm{LiFePO}_{4} / \mathrm{TILGPE} / \mathrm{Li}$ cell possesses very good capacity retention compared to conventional liquid electrolyte (shown in ESI, Fig. S5 and S6†) and it provides a maximum of $149.8 \mathrm{~mA} \mathrm{~h} \mathrm{~g}^{-1}$ at $\mathrm{C} / 10$ rate. These results clearly demonstrate that the $\mathrm{LiFePO}_{4} / \mathrm{TILGPE} 3 / \mathrm{Li}$ has 

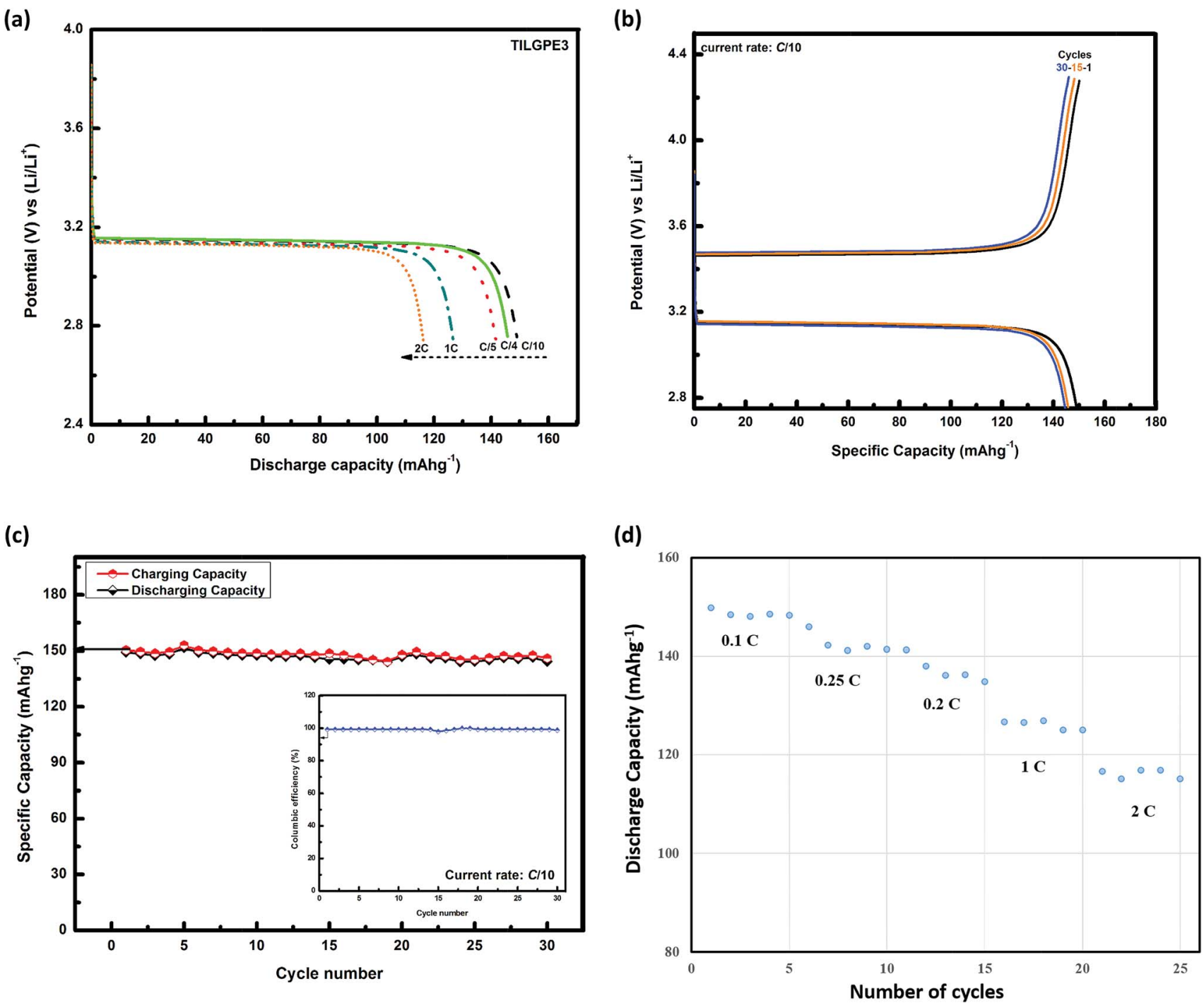

Fig. 10 (a) Discharge capacities of $\mathrm{LiFePO}_{4} / \mathrm{TILGPE3/Li} \mathrm{cell} \mathrm{at} \mathrm{different} \mathrm{C-rates} \mathrm{(b)} \mathrm{charge-discharge} \mathrm{plateau} \mathrm{of} \mathrm{LiFePO} 4 / \mathrm{TILGPE3/Li} \mathrm{cell} \mathrm{at} \mathrm{the}$ $\mathrm{C} / 10$ rate (c) capacity retention curve of $\mathrm{LiFePO}_{4} / \mathrm{TILGPE3} / \mathrm{Li}$ cell at $\mathrm{C} / 10$ (inset: its corresponding columbic efficiency plot as a function of number of cycles at $\mathrm{C} / 10$ rate) (d) capacity retention curve of $\mathrm{LiFePO}_{4} / \mathrm{TILGPE3/Li}$ cell at different C-rates.

a good room temperature cycling performance. The observed findings are in consistent with the earlier reported results. ${ }^{60,61}$

\section{Conclusions}

In summary, for the first time, we have prepared a new class of rhodanide anion based ternary gel polymer electrolyte system and characterized for its application in LIBs. Interactions between ions and polymer are confirmed by the IR shifting of the $\nu(\mathrm{SCN})$ mode of electrolyte mixture as well as the $\nu_{\mathrm{a}}\left(\mathrm{CF}_{2}\right)$ mode of PVdF-co-HFP. The thermal stability of the TILGPEs is marginally increased from 251 to $258{ }^{\circ} \mathrm{C}$ upon the introducing of electrolyte mixture and TILGPE3 provides better thermal stability over other two electrolytes. It displays a high ionic conductivity of $2.8 \times 10^{-2} \mathrm{~S} \mathrm{~cm}^{-1}$ at $398 \mathrm{~K}$ along with an electrochemical stability of $5.2 \mathrm{~V}$. Besides, the transference number of gel electrolyte at ambient temperature is much increased.
Henceforth, the prepared TILGPEs are thermal stable and electrochemically active, which holds great promise for to lithium-ion battery requiring high safety with excellent electrochemical properties. The prepared $\mathrm{LiFePO}_{4} / \mathrm{TILGPE} / \mathrm{Li}$ cell possesses very good capacity retention and it provides a maximum of $149.8 \mathrm{~mA} \mathrm{~h} \mathrm{~g}^{-1}$ at $\mathrm{C} / 10$ rate. We expect that our ternary gel electrolyte system will spur investigation in the scientific community regarding its potential as active separator for applications in future large scale LIBs.

\section{Acknowledgements}

This work is supported by Global Frontier R\&D Program on Center for Multiscale Energy System funded by the National Research Foundation under the Ministry of Science, ICT \& Future Planning, Korea (2011-0031570) and by the Korea Center for Artificial Photosynthesis (KCAP) located in Sogang 
University funded by the Minister of Science, ICT and Future Planning (MSIP) through the National Research Foundation of Korea (No. 2009-0093883) and also supported by the Human Resources Development program (No. 20114010203090) of the Korea Institute of Energy Technology Evaluation and Planning (KETEP) grant funded by the Korea Government Ministry of Trade, Industry and Energy. The author Dr K. K. S. thankfully remembered the help rendered by Dr Amol Uttam Pawar and Kim Katey, Sogang University for their continuous support in characterization studies. The one of the author Dr K. K. S. thankfully acknowledges Dongguk University-Seoul for their financial support.

\section{References}

1 J. M. Tarascon, A. S. Gozdz, C. Schmutz, F. Shokoohi and P. C. Warren, Solid State Ionics, 1996, 86-88, 49-54.

2 J. B. Goodenough and Y. Kim, Chem. Mater., 2010, 587-603.

3 F. Groce, F. Gerace, G. Dautzemberg, S. Passerini, G. B. Appetecchi and B. Scrosati, Electrochim. Acta, 1994, 39, 2187-2194.

4 S. Ferrari, E. Quartarone, P. Mustarelli, A. Magistris, M. Fagnoni, S. Protti, C. Gerbaldi and A. Spinella, J. Power Sources, 2010, 195, 559-566.

5 A. Fernicola, F. C. Weise, S. G. Greenbaum, J. Kagimoto, B. Scrosati and A. Soleto, J. Electrochem. Soc., 2009, 156, A514-A520.

6 V. Gentili, S. Panero, P. Reale and B. Scrosati, J. Power Sources, 2007, 170, 185-190.

7 M. Li, L. Yang, S. Fang, S. Dong, S. I. Hirano and K. Tachibana, Polym. Int., 2012, 61, 259-264.

8 (a) G. T. Kim, G. B. Appetecchi, M. Carewska, M. Joost, A. Balducci, M. Winter and S. Passerini, J. Power Sources, 2010, 195, 6130-6137; (b) W. Wen, J. M. Wu, Y.-Z. Jiang, J.-Q. Bai and L.-L. Lai, J. Mater. Chem. A, 2016, 4, 1059310600; (c) W. Wen, J. M. Wu and M.-H. Cao, Nano Energy, 2016, 2, 1383-1390.

9 M. Armand, F. Endres, D. R. MacFarlane, H. Ohno and B. Scrosati, Nat. Mater., 2009, 8, 621-629.

10 M. A. Navarra, MRS Bull., 2013, 38, 548-553.

11 M. A. Navarra, J. Manzi, L. Lombardo, S. Panero and B. Scrosati, ChemSusChem, 2011, 4, 125-130.

12 S. R. Sivakkumar and D.-W. Kim, J. Electrochem. Soc., 2007, 154, A134-A139.

13 D. R. MacFarlane, N. Tachikawa, M. Forsyth, J. M. Pringle, P. C. Howlett, G. D. Elliott, J. H. Davis, M. Watanabe, P. Simon and C. A. Angell, Energy Environ. Sci., 2014, 7, 232-250.

14 G. B. Appetecchi, M. Montanino, A. Balducci, S. F. Lux, M. Winter and S. Passerini, J. Power Sources, 2012, 219, 371.

15 N. K. Karan, O. K. Pradhan, R. Thomas, B. Natesan and R. S. Katiyar, Solid State Ionics, 2008, 179, 689-696.

16 G. Derrien, J. Hassoun, S. Sacchetti and S. Panero, Solid State Ionics, 2009, 180, 1267-1271.

17 H. Lee, M. Yanilmaz, O. Toprakci, K. Fu and X. Zhang, Energy Environ. Sci., 2014, 7, 3857-3886.
18 Y. Zhu, F. Wang, L. Liu, S. Xiao, Y. Yang and Y. Wu, Sci. Rep., 2013, 3, 3187.

19 C. M. Costa, M. M. Silva and S. Lanceros-Méndez, RSC Adv., 2013, 3, 11404-11417.

20 S. M. Seidel, S. Jeschke, P. Vettikuzha and H.-D. Wiemhöfer, Chem. Commun., 2015, 51, 12048-12051.

21 A. Kumar, R. Sharma, M. K. Das, P. Gajbhiye and K. K. Kar, Electrochim. Acta, 2016, 215, 1-11.

22 H. Gao, B. Guo, J. Song, K. Park and J. B. Goodenough, Adv. Energy Mater., 2015, 5, 1-8.

23 N. Zebardastan, M. H. Khanmirzaei, S. Ramesh and K. Ramesh, Electrochim. Acta, 2016, 220, 573-580.

24 K. Karuppasamy, H. W. Rhee, P. A. Reddy, D. Gupta, L. Mitu, A. R. Polu and X. Sahaya Shajan, J. Ind. Eng. Chem., 2016, 40, 1-9.

25 S. K. Chaurasia, R. K. Singh and S. Chandra, J. Phys. Chem. B, 2013, 117, 897-906.

26 S. K. Chaurasia, V. K. Singh and R. K. Singh, J. Mater. Chem. C, 2015, 3, 7305-7318.

27 G. P. Pandey, T. Liu, C. Hancock, Y. Li, X. S. Sun and J. Li, J. Power Sources, 2016, 328, 510-519.

28 K. Karuppasamy, P. A. Reddy, G. Srinivas, A. Tewari, R. Sharma, X. S. Shajan and D. Gupta, J. Membr. Sci., 2016, 514, 350-357.

29 A. S. Pensado, M. Brehm, J. Thar, A. P. Seitsonen and B. Kirchner, ChemPhysChem, 2012, 13, 1845-1853.

30 G. Hua Sun, K. Xi Li and C. Gong Sun, J. Power Sources, 2006, 162, 1444-1450.

31 M. Ravi, S. Song, J. Wang, R. Nadimicherla and Z. Zhang, Ionics, 2016, 22, 661-670.

32 (a) M. Ravi, S. Song, K. Gu, J. Tang and Z. Zhang, Mater. Sci. Eng., B, 2015, 195, 74-83; (b) A. Hauch and A. Georg, Electrochim. Acta, 2001, 46, 3457-3466; (c) J. Zhang, X. Huang, H. Wei, J. Fu, W. Liu and X. Tang, New J. Chem., 2011, 35, 614-621.

33 R. M. Silverstein, F. X. Webster and D. J. Kimele, Spectroscopic Identifications of Organic Compounds, 7th edn, 2005.

34 P. Periasamy, K. Tatsumi, M. Shikano, T. Fujieda, Y. Saito, T. Sakai, M. Mizuhata, A. Kajinami and S. Deki, J. Power Sources, 2000, 88, 269-273.

35 Q. Zhang, F. Ding, W. Sun and L. Sang, RSC Adv., 2015, 5, 65395-65401.

36 S. Rajendran, O. Mahendran and T. Mahalingam, Eur. Polym. J., 2002, 38, 49-55.

37 M. Suleman, Y. Kumar and S. A. Hashmi, Mater. Chem. Phys., 2015, 1-11.

38 S. Ganesan, B. Muthuraaman, V. Mathew, M. K. Vadivel, P. Maruthamuthu, M. Ashokkumar and S. A. Suthanthiraraj, Electrochim. Acta, 2011, 56, 8811-8817.

39 S. Shalu, L. Balo, H. Gupta, V. kumar Singh and R. K. Singh, RSC Adv., 2016, 6, 73028-73039.

40 R. He and T. Kyu, Macromolecules, 2016, 49, 5637-5648.

41 S. U. Hong, D. Park, Y. Ko and I. Baek, Chem. Commun., 2009, 7227-7229.

42 M. Suleman, Y. Kumar and S. A. Hashmi, J. Phys. Chem. B, 2013, 117, 7436-7443. 
43 W. Li, Y. Xing, X. Xing, Y. Li, G. Yang and L. Xu, Electrochim. Acta, 2013, 112, 183-190.

44 D. Kumar and S. A. Hashmi, Solid State Ionics, 2010, 181, 416-423.

45 H. Kim, S. Park and M. Cho, Phys. Chem. Chem. Phys., 2012, 14, 6233.

46 L. N. Sim, S. R. Majid and A. K. Arof, Solid State Ionics, 2012, 209-210, 15-23.

47 M. H. Abdul Rahaman, M. U. Khandaker, Z. R. Khan, M. Z. Kufian, I. S. M. Noor and A. K. Arof, Phys. Chem. Chem. Phys., 2014, 16, 11527-11537.

48 K. Karuppasamy, S. Thanikaikarasan, R. Antony, S. Balakumar and X. S. Shajan, Ionics, 2012, 18, 737-745.

49 (a) K. Karuppasamy, C. Vijil Vani, R. Antony, S. Balakumar and X. Sahaya Shajan, Polym. Bull., 2013, 70, 2531-2545; (b) S. Abbrent, J. Lindgren, J. Tegenfeldt and A. Ê. Wendsjo, Electrochim. Acta, 1998, 43, 1185-1191.

50 (a) P. Yang, W. Cui, L. Li, L. Liu and M. An, Solid State Sci., 2012, 14, 598-606; (b) H. Akashi, K. Tanaka and K. Sekai, J. Electrochem. Soc., 1998, 145, 881-886.

51 J. R. Kim, S. W. Choi, S. M. Jo, W. S. Lee and B. C. Kim, J. Electrochem. Soc., 2005, 152, A295.
52 P. Raghavan, X. Zhao, H. Choi, D. H. Lim, J. K. Kim, A. Matic, P. Jacobsson, C. Nah and J. H. Ahn, Solid State Ionics, 2014, 262, 77-82.

53 J. Evans, C. A. Vincent and P. G. Bruce, Polymer, 1987, 28, 2324-2328.

54 J. R. Nair, D. Cíntora-Juárez, C. Pérez-Vicente, J. L. Tirado, S. Ahmad and C. Gerbaldi, Electrochim. Acta, 2016, 199, 172-179.

55 J. H. Shin, W. A. Henderson and S. Passerini, Electrochem. Commun., 2003, 5, 1016-1020.

56 I. Stepniak, E. Andrzejewska, A. Dembna and M. Galinski, Electrochim. Acta, 2014, 121, 27-33.

57 J. K. Chang, M. T. Lee, W. T. Tsai, M. J. Deng, H. F. Cheng and I. W. Sun, Langmuir, 2009, 25, 11955-11960.

58 Y. Wang, P. He and H. Zhou, Energy Environ. Sci., 2011, 4, 805-817.

59 T. Eriksson, A. M. Andersson, A. G. Bishop, C. Gejke, T. Gustafsson and J. O. Thomas, J. Electrochem. Soc., 2002, 149, A69-A78.

60 Y. Lin, J. Li, Y. Lai, C. Yuan, Y. Cheng and J. Liu, RSC Adv., 2013, 3, 10722.

61 J. Zhang, B. Sun, X. Huang, S. Chen and G. Wang, Sci. Rep., 2014, 4, 6007. 